\title{
Organizational climate and teamwork at the Family Health Strategy
}

\author{
Clima organizacional e trabalho em equipe na estratégia saúde da família \\ Clima organizacional y trabajo en equipo en la Estrategia Salud Familiar
}

Hellen Emília Peruzzo'
ORCID: 0000-0002-0786-0447

Eraldo Schunk Silva"

ORCID: 0000-0002-6253-5962

Vanessa Carla Batista'

ORCID: 0000-0002-3267-3969

Maria do Carmo Fernandez Lourenço Haddad"'

ORCID: 0000-0001-7564-8563

Aida Maris Peresiv

ORCID: 0000-0003-2913-2851

Sonia Silva Marcon'

ORCID: 0000-0002-6607-362X

'Universidade Estadual de Maringá, Programa de Pós-Graduação em Enfermagem. Maringá, Paraná, Brasil.

"Universidade Estadual de Maringá, Programa de

Pós-Graduação em Estatística. Maringá, Paraná, Brasil.

"'Universidade Estadual de Londrina, Programa de Pós-Graduação em Enfermagem. Londrina, Paraná, Brasil.

"Universidade Federal do Paraná, Programa de Pós-Graduação em Enfermagem. Curitiba, Paraná, Brasil.

How to cite this article: Peruzzo HE, Silva ES, Batista VC, Haddad MCFL, Peres AM, Marcon SS. Organizational climate and teamwork at the Family Health Strategy. Rev Bras Enferm. 2019;72(3):721-7. doi: http://dx.doi.org/10.1590/0034-7167-2017-0770

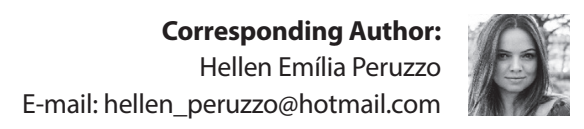

Submission: 02-11-2018 Approval: 03-02-2019

\section{ABSTRACT}

Objective: to measure the organizational climate in the work of professionals from Family Health Strategy (FHS) teams. Method: a cross-sectional study carried out with 458 professionals belonging to 72 FHS teams in a municipality in Southern Brazil. Data collection occurred between March and July of 2016 with self-application of the Team Climate Inventory (TCI). Data were analyzed by means of a non-parametric ANOVA. Results: "Team Participation" was the best-rated domain (8.11), while "Task orientation" was the worst (7.51). Nurses obtained the highest mean in TCI (8.05), and dentists, the lowest (7.45). Conclusion: $\mathrm{TCl}$ is an appropriate and innovative tool for assessing the teamwork climate at the FHS. Identifying fragilities such as "task orientation" and relationships among professional categories of the team supports the planning of actions for organizational climate improvements and teamwork at the FHS.

Descriptors: Work; Patient Care Team; Health Personnel; Interpersonal Relations; Family Health Strategy.

\section{RESUMO}

Objetivo: medir o clima organizacional no trabalho de profissionais das equipes da Estratégia Saúde da Família (ESF). Método: estudo transversal, realizado com 458 profissionais pertencentes a 72 equipes da ESF em um município do Sul do Brasil. Os dados foram coletados entre março e julho de 2016, com autoaplicação da Escala de Clima na Equipe (ECE) e analisados por meio de uma ANOVA não paramétrica. Resultados: "Participação na Equipe" foi o domínio melhor avaliado $(8,11)$, enquanto "Orientação para tarefas", o pior $(7,51)$. Enfermeiros obtiveram a maior média na ECE $(8,05)$, e odontólogos, a menor $(7,45)$. Conclusão: a ECE constitui uma ferramenta adequada e inovadora para avaliar o clima do trabalho em equipe na ESF. A identificação de fragilidades, como "orientação para tarefas" e nas relações entre categorias profissionais da equipe sustenta o planejamento de ações para melhorias do clima organizacional e trabalho em equipe na ESF.

Descritores: Estratégia Saúde da Família; Trabalho; Equipes de Saúde; Profissional da Saúde; Relações Interpessoais.

\section{RESUMEN}

Objetivo: medir el clima organizacional en el trabajo de profesionales de los equipos de la Estrategia Salud Familiar (ESF). Método: estudio transversal, realizado con 458 profesionales pertenecientes a 72 equipos de la ESF en un municipio del sur de Brasil. Los datos fueron recolectados entre marzo y julio de 2016, con el autoaplicación de la Escala de Clima en el Equipo (ECE) y analizados por medio de una ANOVA no paramétrica. Resultados: “La participación en el Equipo" fue el dominio mejor evaluado $(8,11)$; "la orientación para tareas" fue el peor $(7,51)$. Los enfermeros se atribuyeron la mayor media en la ECE $(8,05)$ y los odontólogos, la menor $(7,45)$. Conclusión: la ECE constituye una herramienta adecuada e innovadora para evaluar el clima del trabajo en equipo en la ESF. La identificación de fragilidades como "la orientación para tareas"y, en las relaciones entre las categorías profesionales del equipo, sostiene la planificación de acciones para mejoras del clima organizacional y trabajo en equipo en la ESF.

Descriptores: Estrategia Salud Familiar; Trabajo; Equipos de Salud; Profesional de la Salud; Relaciones Interpersonales. 


\section{INTRODUCTION}

Approaches related to the organizational climate in health teams must follow the principles related to the organization in the work, advocated by the public policies that guide the Brazilian Unified Health System (SUS - Sistema Único Saúde) ${ }^{(1)}$. The organizational climate involves a set of values and formal and informal behaviors. In addition, it is essential to achieve managerial goals, as it affects work process and motivation of workers. However, in order to achieve the goals, it is necessary to promote satisfaction and pleasure in the work environment, minimize hierarchical rigidity, and implement participatory management ${ }^{(2)}$. Team climate also refers to the design of teamwork as it involves the integration and collaboration among members of the same team ${ }^{(3)}$.

The word "team" is strongly associated with the accomplishment of tasks; activities shared between different people and collectively achieve the idealized results. Therefore, the team concept refers to a set of individuals that interact with each other, seeking a common goal, adding to the work process specific knowledge of each of its members, with the aim of building an empowered agreement ${ }^{(4)}$.

Teamwork gained prominence in the health scene from movements in the health area (Community and Preventive Medicine) that aimed, among other things, to replace health practices identified as hospital-centered and doctor-centered by multiprofessional and person-centered teamwork. This proposal is based on the belief that integration and complementarity among the various members of the same health team can interfere in a positive way with the quality of the services offered ${ }^{(5-6)}$.

In order to consolidate teamwork in the field of Health, it is necessary to establish objectives, to have concrete goals well defined and common to the group of workers. Thus, based on individual and group growth, it is possible to contribute to the development of care that is centered on the user and his community ${ }^{(2)}$.

It evolved towards the establishment of objectives, with welldefined concrete goals and common to the group of workers to consolidate teamwork in the area of Health. It is considered that from individual and group growth, teamwork contributes to the development of a more secure care due to the more communicative, participative and collaborative climate centered on the user and the characteristics of the territory/community where he lives ${ }^{(2)}$.

Family Health Strategy (FHS) teams present in the current structural model of Primary Health Care in Brazil, are the main representatives of this model of work, since one of its main pillars is teamwork ${ }^{(1)}$. They are composed of at least one general practitioner, one nurse, one nursing assistant and Community Health Agents (CHA) sufficient to cover $100 \%$ of the registered population, respecting the maximum ceiling of one $\mathrm{CHA}$ for every 750 people, and 12 CHA per FHS team. Oral health members can also be added to the team: dentist, assistant and dental auxiliary ${ }^{(2)}$.

According to the FHS proposal, teamwork should prioritize effective communication among its members, so that its members can act jointly and continuously in performing daily tasks. Other important characteristics of this proposal are multiprofessional work, assessment of the diagnosis of the real needs of the population, joint planning of actions, sharing in the decisions, synchronized participation of all and encouragement to the exercise of social control ${ }^{(4)}$.
Thus, the existence of differentiated professional profiles generates a complex and significant environment that justifies the accomplishment of investigations addressing the interpersonal relations in the corporate environment of these teams. In addition to multiprofessional, the FHS teams are interprofessional, which are important characteristics for health care.

The first characteristic refers to the presence of different professionals working in the same setting. The second is associated to the existence of integration in the work of different professional categories, so that the work of one professional complements that of the other, culminating in better results for the team and for the recipients of what is produced. Both concepts are employed in Primary Care, in order to guarantee the quality of care through the comprehensiveness and continuity of care ${ }^{(7)}$.

Interpersonal conflicts inherent in the corporate context are the main precursors of not doing teamwork, mainly because they are associated with individualism and lack of cooperation, respect, commitment and co-responsibility. On the other hand, open and transparent dialogue, respect and trust among members, the existence of spaces for discussion of ideas, conflict management and the valorization of teamwork can contribute to the maintenance of healthy interpersonal relationships and, therefore, facilitate the good development of teamwork ${ }^{(8)}$.

However, in the context of the work it is common the existence of pseudo-teams characterized by low integration among its members, non-effective communication and non-collaborative behavior. These problems may also occur in FHS teams and negatively influence the quality of care provided for people $\mathrm{e}^{(9-10)}$.

There are many factors favoring the emergence of pseudoteams and may range from unresolved ethical conflicts to the isolation of assignments from distinct professional categories, which inhibits interprofessional cooperation. Bioethical implications resulting from job losses of a particular professional category, which compromises the care of the user, also favors the emergence of pseudo-teams. The manager should devote attention to professionals who integrate the team and to the relationships among them to reverse this process ${ }^{(5,11)}$.

The importance of teamwork and its impact on the results obtained within the scope of the FHS may even integrate the discussion patterns of managers and the team itself, but are still little discussed in scientific research. However, these guidelines are important to understand issues closely involved in the interpersonal and multiprofessional relations of Primary Care, in order to identify strategies of changes that can contribute to the improvement of the work process and, consequently, the assistance offered to users ${ }^{(6)}$.

\section{OBJECTIVE}

This study aims to measure the organizational climate in the work of professionals of the Family Health Strategy.

\section{METHOD}

\section{Ethical aspects}

The study was developed in accordance with Resolution 446/12 of the National Health Council. The Standing Committee on Ethics in 
Research Involving Human Beings approved this study. All the participants signed the Free and Informed Consent Form in two copies.

\section{Design, place of study and period}

The research is characterized as a non-probabilistic transversal, with quantitative approach, performed in 34 Basic Health Units (BHU) of a municipality in the South of Brazil, from March to July 2016.

\section{Population or sample; inclusion and exclusion criteria}

Professionals from 72 out of the 74 FHS teams in the county were part of the study, as members of two teams implicitly declined to participate. The number of members of each team was not taken into account, since the analysis did not consider each team as unit to be assessed, but rather, the individual in its singularity. Thus, the number of team members who accepted to participate in the study ranged from three to ten.

458 of the 587 professionals working at the FHS in the city under study were part of the study, including: nurses, doctors, dentists, nursing assistants/technicians, dental auxiliaries and CHA. Professionals who worked in the teams less than 30 days were excluded.

\section{Study protocol}

The invitation to participate in the survey was conducted for all FHS professionals present at the time of the meeting previously scheduled with the director of each BHU. For data collection, participants were asked to complete two tools, one for sociodemographic data collection, and the Team Climate Inventory $(\mathrm{TCl})$, whose purpose is to assess the climate in the proximal working groups ${ }^{(3)}$.

The English, Michel A. West and Neil R. Anderson prepared $\mathrm{TCl}$, in a 38-item Likert-type scale format with the objective of obtaining data referring to four factors: Team Participation, with 12 items (graduated between 1 to 5 points each item). Team Objectives had 8 items (graduated between 1 and 5 points). Support for new ideas had 11 items (graduated between 1 and 7 points). Tasks orientation had 7 items (graduated between 1 and 7 points). The minimum score of the tool corresponds to 38 points and, the maximum, to 226 points ${ }^{(3)}$.

Team Participation factor addresses issues such as sharing of information, influences on others, feeling of being heard/accepted by the group and maintaining constant contact. Support for new ideas encompasses issues related to the expectations and approval members receive from the team for the introduction of new tools in the work process. Team Objectives factor explores how clear objectives/goals are for all its members. Lastly, Tasks orientation factor addresses topics such as monitoring for high performance standards, clear criteria for achieving excellence as a team, and whether there are assessments and suggestions for improvement ${ }^{(3)}$.

\section{Analysis of results, and statistics}

Quantitative variables were summarized by means of the weighted mean and mean score. The groups were compared by the Kruskal-Wallis test, followed by Dunn's Multiple Comparison Test (differentiated by superscript letters "a" and "b"). A 95\% confidence level was considered. Analyzes were performed by the Statistical Analysis Software (SAS, version 9.0) program (12), from a database built through the Excel program.

It is noteworthy that in the translation of $\mathrm{TCl}$ to Portuguese, no parameters were considered for classification of the data. Thus, in this study, the final scores of the items were transformed into a scale of zero to 10 to compare the data and better exploitation of the results.

\section{RESULTS}

Of the 458 professionals of the FHS teams interviewed, 57 (12.44\%) were nurses, 37 (8.07\%) doctors, 20 (4.36\%) dentists, 47 (10.26\%) nursing assistants/technicians, 19 (4.14\%) dental auxiliaries and technicians and 278 (60.69\%) CHA. Of the 587 professionals belonging to the teams, 26 refused to participate in the study; 33 were on vacation; 39 in a medical certificate; nine were in medical or maternity leave; ten were not present in the $\mathrm{BHU}$; and $12 \mathrm{CHA}$ belonged to the itinerant team of the rural area.

$406(88.65 \%)$ women participated in the study. The age of the interviewees ranged from 18 to 73 years (mean of 41.84 years). Working time ranged from one month to 48 years (mean of 9 years). Working time in the city hall varied between one month and 30 years (mean of 6.83 years). Time of action at Primary Care varied between one month and 21.33 years (mean of 5.71 years); and time in the same FHS team, between one month and 21.33 years (mean of 5.52 years).

Of the 72 teams that participated in the research, 22 had dental health staff integrated with the FHS. Five of them, at the time of data collection, were without the presence of the doctor between one and two months. Working time with the same team formation was around a year and a half, ranging from one month to 12 years.

As for the four factors assessed in the TCl that make it possible to identify the climate in teamwork, Table 1 shows a significant difference $\left(p=0.0001^{*}\right)$ only in relation to the mean attributed to the Team Participation factor (8.11). The lowest factor scored by the participants was the Task orientation's (7.51).

Table 1 - Overall score attributed by the Family Health Strategy teams to each of the factors assessed by the Team Climate Inventory, municipality of Southern Brazil, 2016

\begin{tabular}{lccccc}
\hline Factor & N & Mean Grade & Mean Score & $\boldsymbol{X}^{2}$ & P value \\
\hline Team Participation & 72 & 8.1155276 & $150.541667^{\mathrm{b}}$ & 37.47 & $0.0001^{*}$ \\
Support for new ideas & 48 & 7.7801182 & $111.520833^{\mathrm{a}}$ & & \\
Team Objectives & 66 & 7.6982092 & $100.674242^{\mathrm{a}}$ & \\
Task orientation & 42 & 7.5170016 & $77.845238^{\mathrm{a}}$ & & \\
\hline
\end{tabular}

Note: *Significant at the $95 \%$ confidence level $(a=0.05)$. Numbers marked with the same lette do not differ from each other by the Kruskal-Wallis test, followed by the Dunn's Test.

In relation to the overall score of the $\mathrm{TCl}$, it can be observed that the dentists presented a significant difference in relation to the other professionals $\left(0.0001^{*}\right)$, with the lowest overall mean in the tool (7.45). Next came the dental auxiliaries (7.60), CHA (7.85) and doctors (7.90). On the other hand, the highest means were for nurses (8.05) and nursing assistants/technicians (8.02) (Table 2).

Finally, in Table 3, it is present overall marks attributed by the different professional categories to the four factors of the $\mathrm{TCl}$. There was a significant difference in three of the four factors: Team Participation $\left(p=0.0030^{*}\right)$, Support for new ideas $\left(p=0.0005^{*}\right)$ and Task orientation $\left(\mathrm{p}=0.0082^{*}\right)$. 
Table 2 - Overall score attributed by the professional categories of the Family Health Strategy to Team Climate Inventory, municipality of Southern Brazil, 2016.

\begin{tabular}{lcccc}
\hline Occupation & Mean Grade & Mean Score & $\boldsymbol{X}^{\mathbf{2}}$ & P value \\
\hline Nurse & 8.05 & $141.947368^{\mathrm{a}}$ & 36.90 & $0.0001^{*}$ \\
Nursing Technician & 8.02 & $142.118421^{\mathrm{a}}$ & & \\
Doctor & 7.90 & $124.039474^{\mathrm{a}}$ & & \\
Community Health Agents & 7.85 & $119.421053^{\mathrm{a}}$ & & \\
Deantal Auxiliary & 7.60 & $89.131579^{\mathrm{a}}$ & & \\
Dentist & 7.45 & $70.342105^{\mathrm{b}}$ & & \\
\hline
\end{tabular}

Note: *Significant at the $95 \%$ confidence level $(a=0.05)$. Numbers marked with the same letter do not differ from each other by the Kruskal-Wallis test, followed by the Dunn's Test.

Table 3 - Overall score attributed by the professional categories of the Family Health Strategy to the factors assessed by Team Climate Inventory, municipality of Southern Brazil, 2016

\begin{tabular}{lcccc}
\hline Factor assessed & Mean Grade & Mean Score & $X^{2}$ & P value \\
\hline Team Participation & & & & \\
Community Health Agent & 8.03 & $32.458333^{\mathrm{a}}$ & 17.93 & $0.0030^{*}$ \\
Dental Auxiliary & 7.91 & $27.750000^{\mathrm{a}}$ & & \\
Dentist & 7.70 & $21.125000^{\mathrm{b}}$ & & \\
Nurse & 8.42 & $47.875000^{\mathrm{a}}$ & & \\
Doctor & 8.45 & $50.125000^{\mathrm{a}}$ & & \\
Nursing Technician & 8.19 & $39.666667^{\mathrm{a}}$ & & \\
Support for new ideas & & & & \\
Community Health Agent & 7.92 & $28.31250^{\mathrm{a}}$ & 22.26 & $0.0005^{*}$ \\
Dental Auxiliary & 7.76 & $21.81250^{\mathrm{a}}$ & & \\
Dentist & 7.20 & $6.87500^{\mathrm{b}}$ & & \\
Nurse & 8.01 & $32.81250^{\mathrm{a}}$ & & \\
Doctor & 7.68 & $21.18750^{\mathrm{a}}$ & & \\
Nursing Technician & 8.11 & $36.00000^{\mathrm{a}}$ & & \\
Team Objectives & & & & \\
Community Health Agent & 7.76 & $35.545455^{\mathrm{a}}$ & 7.61 & 0.1789 \\
Dental Auxiliary & 7.40 & $22.409091^{\mathrm{a}}$ & & \\
Dentist & 7.54 & $27.363636^{\mathrm{a}}$ & & \\
Nurse & 7.85 & $38.727273^{\mathrm{a}}$ & & \\
Doctor & 7.76 & $35.909091^{\mathrm{a}}$ & & \\
Nursing Technician & 7.89 & $41.045455^{\mathrm{a}}$ & & \\
Tasks orientation & & & & \\
Community Health Agent & 7.61 & $23.928571^{\mathrm{a}}$ & 15.5538 & $0.0082^{*}$ \\
Dental Auxiliary & 7.20 & $13.500000^{\mathrm{b}}$ & & \\
Dentist & 7.19 & $12.285714^{\mathrm{b}}$ & & \\
Nurse & 7.80 & $30.714286^{\mathrm{a}}$ & & \\
Doctor & 7.44 & $18.000000^{\mathrm{a}}$ & & \\
Nursing Technician & 7.86 & $30.571429^{\mathrm{a}}$ & & \\
\hline
\end{tabular}

Note: *Significant at the $95 \%$ confidence level $(a=0.05)$. Numbers marked with the same letter do not differ from each other by the Kruskal-Wallis test, followed by the Dunn's Test.

\section{DISCUSSION}

The fact that the Team Participation factor was better assessed by professionals suggests that aspects such as information sharing, the feeling of being heard/accepted by the group and the maintenance of constant contacts are being well developed by the teams. Different from what was observed in the Task orientation factor that obtained the lowest mean. Although there is no significant difference in relation to the means attributed to the other two factors, the fact that the Task orientation factor has obtained the lowest mean is worrisome, since it values the perception about the responsibility of the group and of each one of its members in accomplishing the tasks with quality ${ }^{(3)}$.

The Support for new ideas and Team Objectives factors presented near and intermediate means. This shows that, in general, team goals are reasonably perceived as clear to all members and that the group considers new ideas. These aspects are important because the clearer the Team Objectives are, the more empowered their members will be to develop the proposals; and the more members realize that their ideas are considered by the group, the more motivated they are to present new ideas and this tends to qualify the care that is provided ${ }^{(3)}$.

Means attributed by the different professional categories show that there is a significant difference in perception on the team climate only by dentists, and means are attributed by very similar doctors and nurses, which is justified by the strong integration among these two professionals in the environment of job $^{(5)}$. It is noteworthy that nurses were professionals who assigned the highest mean in $\mathrm{TCl}$.

It should be emphasized that in the scope of Primary Care, it is the responsibility of this category, besides providing direct care for the population, to provide clinical support in the organization of care, to supervise, but also to plan, manage and assess the activities developed by the CHA together with the others members of the FHS team. In addition, participate in the management of the necessary inputs for the maintenance of the operation of the $\mathrm{BHU}$. In addition, it is through the nurse that general guidelines for the development of services, necessary information for the management of conflicts and active dialogue among users, follow-up, being the nurse the communication mediator ${ }^{(13) .}$

In this sense, the nurse acts by taking responsibility and aiming at the co-responsibility of the whole team, encouraging the active participation in the meetings, articulating the different opinions, elaborating the intervention strategies, impelling the team in the implementation and direction of the actions, always prioritizing a constant integration among its members ${ }^{(13)}$.

However, although the nurse does not have the formal leadership role of all FHS members, in practice he is the professional who performs coordination in the primary care teams. By the way, he is the bestprepared professional for this assignment; however, attention should be paid to the accumulation of activities, exercised by this category, since they already perform multiple tasks, and this condition, in addition to bringing overload, can also contribute to negative impacts in the sharing of the production of teamwork ${ }^{(14)}$.

The fact that they assign a higher mean in the $\mathrm{TCl}$ shows that the nurses in study have a favorable perception in relation to the other professionals and believe that the essential elements for the good performance of the team are being well executed. In contrast, one must consider that, as the nurse sometimes has a leadership role in the team, the same tends to assess it in a positive way. Nurses are the professionals responsible for keeping the members motivated, well informed about the team objectives and oriented about the tasks to be performed, 
as well as offering support for new ideas and encouraging the participation of all ${ }^{(15)}$.

On the other hand, are the members of oral health, who attributed the lowest scores in the TCI. Professionals' inclusion in the FHS began in 2001, with the purpose of offering oral health care in all regions of the country, having as central axis the family. The aim was to deconstruct the curative-mutilator model to consolidate a new format of attention with a view to promoting the oral health of school children, which could broaden the epidemiological indices of oral health and expand the Brazilian population's access to dental services ${ }^{(1)}$. Due to these aspects, the difficulties of working in a team, experienced by dentists and oral health aides and evidenced from this study, may be due to a fragile implementation process, regarding interpersonal relations. Since new professionals have been incorporated into an already organized team and an ongoing work process.

When assessing the score attributed to each of the four factors by professional category, it is observed in Table 3 that only the Team Objectives factor did not present a significant difference. Considering that the overall mean attributed to this factor is not very high, this result shows that, minimally, all team members know the team objectives. This aspect is because agreements and strategies existing in this assistance area are architected in the different governmental spheres. It is up to the professionals who are at the care to follow previously established goals and also the fact that many of them are already settled in the context of the FHS, that is, they are already part of the activities performed by these professionals for some time ${ }^{(1)}$.

Regarding the assessment by factors, only the dentists differed significantly in the means attributed to the Team Participation factor, and doctors and nurses obtained very similar means, which is justified by the strong integration between these two professionals in the work environment ${ }^{(5)}$. The high score attributed by the $\mathrm{CHA}$ to this factor is explained by the fact that these professionals, in addition to being in greater numbers in the teams of the FHS, are the ones that articulate their activities with the other members ${ }^{(5)}$. Regarding the members of oral health, although there is complementarity and interdependence in relation to the team, they still face difficulties in information exchange and involvement in activities, which limits and restricts their participation in team activities and, consequently, continuity of care, as well as the integrality of care ${ }^{(5)}$.

Team Participation factor refers to the safety of team members in participating in it, exposing their ideas and perceptions in decision making without the fear of being censored or judged. When this joint participation exists within the teams, the result for work innovation is positive ${ }^{(3)}$.

A study carried out in the city of Goiânia, Brazil, investigated the vision of FHS members about the ideal characteristics of a dental surgeon to act in this care model. The study found that for them, this professional, as much as the others who work at the FHS, must have professional skills to work in the field of Public Health and interpersonal skills characterized by communication skills, good relationships, ethics, creativity in difficult situations and emotional balance. FHS workers, therefore, see fragilities in the dental surgeon's performance regarding management with people in less favored socioeconomic conditions and believe that this is due to deficiencies in the academic training that prepares the professional for the provision of care based on technical knowledge scientific, but not to promote social interaction ${ }^{(16)}$.

Although the literature points to advances in the insertion of oral health in the FHS, there is still resistance on the part of professionals, both on the part of the members of this sub-staff and of the other FHS members, especially regarding the incorporation of new practices such as home visits by dentists. Behavior that is due to a culture historically built on the basis of care, where mechanized activities performed in private practices began to be incorporated into Primary Care services, but in a new perspective $^{(17)}$. Oral health activities, formerly curativists, receive the FHS's perspective, with a view to integrated care and preventive focus.

Non-involvement of members in the activities developed by the FHS resulted in low team participation. Corroborating this assertion, in Rio Grande do Sul State, a study was carried out with the objective of providing the FHS teams with a space for assessment and discussion of their interpersonal relations. It was evidenced the feeling of distancing of the technical team (nurse, doctor and nursing technician) in relation to the CHA. This perception was based on the fact that this sub-team did not carry out home visits with the same frequency as the CHA, besides not being obliged to report to them ${ }^{(18)}$.

Still on this research, another important aspect identified as an obstacle in the participation of members was the high turnover of professionals, especially nurses and doctors. This was because, with each change and/or insertion of a new professional, the team needed to modify and adapt to the profile of these "new" professionals. This discontinuity does not favor the existence of a sense of group identity and the members of the team begin to act as executors of curative actions, which hinders the consolidation of the work teams ${ }^{(18)}$. In addition, it can affect the consolidation of the bond among its members, those with the population and also their responsibility for the health care of their territory ${ }^{(16)}$.

Support for newideas is somewhat tied to Team Participation, since non-integration among FHS members discourages the expression of new ideas, which, once unexplained, cannot be supported. Dentists, for example, are the most dissatisfied with this aspect, which allows us to infer that they do not feel that their suggestions are fully embraced by the rest of the team. Therefore, being open to new ideas in the different health contexts is one of the basic elements for more effective relationships and, consequently, for coping with adverbs, as well as promoting greater trust and participation of professionals ${ }^{(19)}$.

Like Support for new ideas, Tasks orientation is important for the development of daily work. It should be emphasized that oral health professionals, once again, were the ones that less valued this aspect in their teams. However, it is necessary to emphasize the need for flexibility in the division and accomplishment of tasks, because although there are private actions for each professional area, there are also activities that can be performed from the multiprofessional interaction. Separation of tasks among team members can often be a tool for organizing the work process, but it can also result in the fragmentation of work ${ }^{(20)}$.

Although the policy guiding the actions of FHS teams is the same, the way each team manages its activities differs, depending on the individual characteristics of professionals that integrate it and the teams as a whole. To this end, the results achieved by 
Organizational climate and teamwork at the Family Health Strategy Peruzzo HE, Silva ES, Batista VC, Haddad MCFL, Peres AM, Marcon SS.

the work teams and the mechanisms for their accomplishment will depend on the particularities in the way of working and the interpersonal relations established among professionals that are part of each group ${ }^{(18)}$. In other words, team development will depend on the influence exerted by the leader and, in particular, on how he will lead the members to achieve the goals they draw ${ }^{(11)}$.

Territorialisation and organization of the demand need to have their incorporation by the FHS teams, especially for oral health, inserted later in this context. However, the relationships of teamwork with a view to the integration and interrelation among health professionals, as well as the fragmentation and individualization of care, are the great difficulties in this context ${ }^{(21)}$.

Interdisciplinarity is one of the essential characteristics for the work process of the FHS teams and should be valued as such. In this sense, the teams also have the challenge of integrating different professional categories into their work process, considering the need for assistance to the population in accordance with SUS principles: comprehensiveness, universalization, decentralization and community participation ${ }^{(17)}$.

In the context of the FHS, in particular, there are gaps in the work process that limit comprehensive health care as a common principle to the interdisciplinary team. In this way, the development of activities is often based on isolated actions based on the individual knowledge of each professional and not shared among all team members ${ }^{(21)}$. In Brazil, professional training of health workers does not encourage the experiences in interdisciplinary teams ${ }^{(22)}$. Differently, in other realities that are seeking this approach, interdisciplinarity is seen as a tool for improving collaborative skills and essential for the practice of quality care ${ }^{(23-24)}$.

In this context, interprofessional collaboration has a prominent role among health professionals, since it constitutes an important tool for higher quality and reduction of spending by health services. Moreover, it is an opportunity to match the power relations between these professionals. In view of this, there must be consistent negotiation processes between the different professional categories, largely dedicated to deconstructing the domain of a single profession over others and placing interprofessional power relations equally ${ }^{(25)}$.

Moreover, there should be addition of new models and shared management strategies to the FHS teams so that there is a greater interrelation of knowledge and cohesion among their members, such as shared leadership. Providing professionals with the opportunity to participate in decisions and goals contributes positively to team identification and performance ${ }^{(23)}$. This reality points to the need for major changes in the training of human resources for health, in order to raise awareness, in particular, of social, structural and cultural dynamics, from interprofessional educational modules for students. Training investments are also important, especially if they consist of training focused on specific contexts of Primary Care ${ }^{(22,25)}$.

\section{Study limitations}

A possible limitation of the study refers to the high number of refusals to participate in the study, which may relate to the fact that data collection occurred during work shift.

\section{Contributions to the field of Nursing, Health or Public Policy}

The study sought to elucidate issues experienced daily by FHS team members and to encourage the reflection of the work process of these professionals; whether in the short or long term, in order to provide improvements in the labor relations and, consequently, in the quality of health care offered to the community. Results of the study may collaborate with investigations about interpersonal relations in Primary Care, especially in the FHS, encouraging professionals for the reflection of the practice and possible changes in the work process of the team.

\section{CONCLUSIONS}

The use of $\mathrm{TCl}$ was an important tool for the assessment of the perception about the organizational climate in the teamwork among FHS professionals. From this point of view, there was identification of fragilities in relation to each other, so that the nurses were the ones who better assessed their teams and, the dentists, the ones who assessed the worst.

These aspects reinforce the existence of inherent challenges in the work environment of professionals who work at Primary Health Care, such as the fulfillment of the precepts of working in teams. However, they instigate further research in this context to understand this phenomenon better, since multiprofessional relationships may interfere directly or indirectly with the quality of care offered to users.

Although they recognize the involvement of the other members in the activities developed by the team, professionals showed that they feel the need to perform tasks by each of them to be better oriented. In this sense, the nurse, as coordinator of the team, needs to assume his role as an important member of this process. Concomitantly, there should be development of strategies by health services to increase the empowerment of the nursing professional, in order to allow greater integration among team members, as well as healthier working relationships and, consequently, the encouragement and maintenance of teamwork.

In addition, there should be discussions on the continued individualization of care in Primary Care, which is one of the main assumptions of the FHS - comprehensive care. In order to minimize the effects of this aspect, in addition to reflections implemented in this setting, it is necessary to elaborate innovative action plans, supported, for example, by the results of this research, and focusing on the training of defragmented professionals and prepared to work in a team.

\section{REFERENCES}

1. Pinto HA, Souza ANA, Ferla AA. [The national program for access and quality improvement in primary care: faces of an innovative policy]. Saúde Debate [Internet]. 2014 [cited 2017 Jul 23];38(esp):358-372. Available from: http://dx.doi.org/10.5935/0103-1104.2014S027 Portuguese.

2. Agreli FH, Peduzzi M, Bailey C. The relationship between team climate and interprofessional collaboration: Preliminary results of a mixed 
Organizational climate and teamwork at the Family Health Strategy Peruzzo HE, Silva ES, Batista VC, Haddad MCFL, Peres AM, Marcon SS.

methods study. J Interprof Care [Internet]. 2017 [cited 2019 Mar 15];31(2):184-6. Available from: http://dx.doi.org/10.1080/13561820.2016.1 261098

3. Silva MC. Adaptação transcultural e validação de instrumento de avaliação de trabalho em equipe: Team Climate Inventory no contexto da Atenção Primária à Saúde no Brasil [Dissertation on the Internet]. São Paulo: Escola de Enfermagem da Universidade de São Paulo; 2014 [cited 2017 Jun 10].Available from: http://www.teses.usp.br/teses/disponiveis/7/7140/tde-30102014-165103/fr.php

4. Agreli FH, Peduzzi M, Bailey C. Contributions of team climate in the study of interprofessional collaboration: a conceptual analysis. J Interprof Care [Internet]. 2017 [cited 2019 Mar 15];31(6):679-84. Available from: http://dx.doi.org/10.1080/13561820.2017.1351425

5. Pereira RCA, Riveira FJU, Artmann E. [The multidisciplinary work in the family health strategy: a study on ways of teams]. Interface Comun Saúde Educ [Internet]. 2013 [cited 2017 Jun 12];17(45):327-40. Available from: http://dx.doi.org/10.1590/S1414-32832013005000006 Portuguese.

6. Peruzzo HE, Silva ES, Haddad MCFL, Marcon SS. Influência do sexo, idade e tempo de atuação na percepção sobre o trabalho em equipe. Rev Min Enferm [Internet]. 2017 [cited 2018 Jun 15];21:e-1011. Available from: http://www.reme.org.br/artigo/detalhes/1147

7. Silva JC, Contim D, Ohi RIB, Chavaglia SRR, Amaral, EMS. Perception of the residents about their performance in the multidisciplinary residency program. Acta Paul Enferm [Internet]. 2015 [cited 2018 Jun 17];28(2):132-8. Available from: http://dx.doi. org/10.1590/1982-0194201500023

8. Fernandes HN, Thofehrn MB, Porto AR, Amestoy SC, Jacondino MB, Soares MR. Interpersonal relationships in work of multiprofessional team of family health unit. J Res Fundam Care Online [Internet]. 2015 [cited 2018 Jun13];7(1):1915-26. Available from: http://dx.doi. org/10.9789/2175-5361.2015.v7i1.1915-1926

9. West MA, Lyubovikova J. Real teams or pseudo teams? the changing landscape needs a better map. Industrial Organizational Psycho [Internet]. 2012 [cited 2019 Mar 15];5:25-55. Available from: https://doi.org/10.1111/j.1754-9434.2011.01397.x

10. West MA, Lyubovnikova J. Illusions of team working in health care. J Health Organ Manag [Internet]. 2013 [cited 2019 Mar 15];27(1):134-42. Available from: http://dx.doi.org/10.1108/14777261311311843

11. Marin SM, Witt RR. Hospital nurses' competencies in disaster situations: a qualitative study in the south of brazil. Prehosp Disaster Med [Internet]. 2015 [cited 2017 Jun 19];30(6):548-52. Available from: http://dx.doi.org/10.1017/S1049023X1500521X

12. Stokes ME, Davis CS, Koch GG. Categorical data analysis using sas system. 2th ed. Cary: Statistical Analysis System Institute, 2000.

13. Lanzoni GMM, Meirelles BHS. [Nurse leadership: intervening element in the relationships network of the community health care agent]. Rev Bras Enferm [Internet]. 2013 [cited 2017 Jun 10];66(4):557-63. Available from: http://dx.doi.org/10.1590/S0034-71672013000400014 Portuguese.

14. Seidl H, Vieira SP, Fausto MCR, Lima RCD, Gagno J. [Labor management in Primary Health Care: an analysis from the perspective of PMAQ-AB participating teams]. Saúde Debate [Internet]. 2014 [cited 2017 Jul 11];38(Especial): 94-108. Available from: http://dx.doi.org/10.5935/01031104.2014S008 Portuguese .

15. Lima FS, Amestoy SC, Jacondino MB, Trindade LM, Silva CN, Jr PRBF. The exercise of leadership of nurses in the family health strategy. J Res Fundam Care [Internet]. 2016 [cited 2017 Jul 24];8(1):3893-3906. Available from: http://dx.doi.org/10.9789/2175-5361.2016.v8i1.3893-3906

16. Soares EF, Reis SCGB, Freire MCM. [Ideal characteristics of the dental surgeon in the family health strategy]. Trab Educ Saúde [Internet]. 2014 [cited 2017 Jul 20];12(2):327-41. Available from: http://dx.doi.org/10.1590/S1981-77462014005000001 Portuguese.

17. Giudice ACMP, Pezzato LM, Botazzo C. [Evaluation practices: reflections on the integration of oral health in the Family Health Team]. Saúde Debate [Internet]. 2013 [cited 2017 Jul 10];37(96):32-42. Available from: http://dx.doi.org/10.1590/S0103-11042013000100005 Portuguese.

18. Araujo MBS, Rocha PM. [Teamwork: a challenge for family health strategy consolidation]. Ciênc Saúde Coletiva [Internet]. 2007 [cited 2017 Jul 24];12(2):455-64. Available from: http://dx.doi.org/10.1590/S1413-81232007000200022 Portuguese.

19. Froneman K, Du Plessis E, Koen MP. Effective educator-student relationships in nursing education to strengthen nursing students' resilience. Curationis [Internet]. 2016 [cited 2018 Jun 26];39(1):1595. Available from: http://dx.doi.org/10.4102/curationis.v39i1.1595

20. Jacowski M, Budal AMB, Lemos DS, Ditterich RG, Buffon MCM, Mazza VA. [Teamwork: the professional's perception of family health strategy]. Rev Baiana Enferm [Internet]. 2016 [cited 2018 Jun 26];30(2):1-9. Available from: http://dx.doi.org/10.18471/rbe.v30i2.15145 Portuguese.

21. Finkler AL, Toso BRGO, Viera CS, Obregón PL, Rodrigues RM. The process of work in primary health care to children. Ciênc Cuid Saude [Internet]. 2016 [cited 2017 Jul 11];15(1):171-9. Available from: http://dx.doi.org/10.4025/cienccuidsaude.v15i1.27683

22. Matos GCM, Ferreira EF, Leite ICG, Greco RM. [The inclusion of the oral health team in the brazilian family health strategy: barriers, advances and challenges]. Cienc Saude Coletiva [Internet]. 2014 [cited 2017 Jul 12];19(2):373-82. Available from: http://dx.doi.org/10.1590/141381232014192.21652012 Portuguese.

23. Dulaya M, Bowenc JL, Weppnere WG, Eastburna A, Poppeg AP, Spanos P, et al. Interprofessional population health advocacy: developing and implementing a panel management curriculum in five veterans administration primary care practices. J Interprof Care [Internet]. 2018 [cited 2018 Jun 19];10:1-11. Available from: http://dx.doi.org/10.1080/13561820.2018.1469476

24. Brashers V, Erickson JM, Blackhall L, Owen JA, Thomas SM, Conaway MR. Measuring the impact of clinically relevant interprofessional education on undergraduate medical and nursing student competencies: a longitudinal mixed methods approach. J Interprof Care [Internet]. 2016 [cited 2018 Jun 19];30(4):448-57. Available from: https://doi.org/10.3109/13561820.2016.1162139

25. Christof S, Gina A, Peter B. Challenges in interprofessionalism in swiss health care: the practice of successful interprofessional collaboration as experienced by professionals. Swiss Med Wkly [Internet]. 2017 [cited 2018 Jun 20];147:w14525. Available from: http://dx.doi.org/10.4414/ smw.2017.14525 